\title{
Paideusis
}

\section{Plato's Metaphysics of Education (Samuel Scolnicov)}

Steve R. Hreha

Volume 4, Number 2, 1991

URI: https://id.erudit.org/iderudit/1073384ar

DOI: https://doi.org/10.7202/1073384ar

See table of contents

Publisher(s)

Canadian Philosophy of Education Society

ISSN

0838-4517 (print)

1916-0348 (digital)

Explore this journal

Cite this review

Hreha, S. (1991). Review of [Plato's Metaphysics of Education (Samuel

Scolnicov)]. Paideusis, 4(2), 42-43. https://doi.org/10.7202/1073384ar viewed online.

https://apropos.erudit.org/en/users/policy-on-use/ 


\section{Book Reviews}

\section{Samuel Scolnicov, Plato's Metaphysics of Education (New York: Routledge, 1988).}

Scolnicov's book is among several to be published by Routledge in its current "Philosophy of Education Research Library" series. Scolnicov provides the reader with a comprehensive and scholarly overview of the historical, cultural, and philosophical background against which Plato developed his views on the nature of education. Customary treatments of Plato's philosophy of education generally take The Republic, Meno, and Laws as sufficient for the delineation of his views. Scolnicov, however, rejects this approach as too narrow and proceeds, instead, to incorporate into his discussion a much broader range of Platonic dialogues (he includes Gorgias, Euthydemus, Theaetetus, Protagoras, Phaedrus, and Symposium). The resulting interpretation of Plato (in particular Scolnicov's unpacking of the metaphysical and epistemological presuppositions of Plato's educational theory) is instrumental in providing a clearer, deeper, and richer understanding of Plato's views. Scolnicov's emphasis upon historical and philosophical context (a virtue unfortunately rare among analytical philosophers of education) is the chief merit of his work.

The major premise of the book is that Plato's views on the nature of education preceded the development of his metaphysics and epistemology. Plato's views on education, he suggests, emerged, in part, as a deeply felt reaction to the burgeoning influence of the Sophists in fifth century Athens, and partly as the result of his efforts to integrate Socrates' inchoate teaching into his own evolving view of the nature of truth, goodness, and beauty. Given his views on education, Plato was led to a dialectical investigation of the presuppositions inherent in the positions adopted by the leading Sophists of the day on the nature of truth and goodness (and whether or not these could be taught). As a result, suggests Scolnicov, he was forced to conclude that these presuppositions were untenable. Plato was, thus, led to formulate an alternative set of metaphysical and epistemological hypotheses. These alternative hypotheses became the ground of his educational theory. Chief among these were Plato's theory of forms and his conception of anamnesis and its role in learning and knowing. Over the course of Scolnicov's discussion, Plato's views are seen to follow from his employment of the very method he delineates and defends in the dialogues under consideration.

The book consists of an "Introduction" and eleven chapters with extensive endnotes providing an informative "contrapuntal" accompaniment to the main theme. In each of the eleven chapters one, or several, of Plato's dialogues are discussed with a view to elucidating the metaphysical and epistemological underpinnings of his theory of education. Taken together, they present a detailed and coherent picture of Plato's view. The endnotes for each chapter are preceded by a short and judiciously selected bibliography of secondary sources.

Of the eleven chapters in Scolnicov's book, I found his discussion in Chapters 8,9,10, and 12 to be especially interesting. In Chapter 8, he examines, in some detail, Plato's conception of anamnesis and its role in knowing 
and learning as presented in Thaeatetus. Plato's understanding of recollection, learning, and knowledge as presented in this dialogue, he argues, diverges significantly from his earlier view developed in Meno. Scolnicov shows that Plato's "new" understanding required substantive revision of common-sense metaphysical assumptions. In Chapter 9, drawing upon Phaedrus and Symposium, he presents Plato's conception of the relation between desire and reason and his belief that one can, in fact, be "mistaken" about what one takes to be one's "real" aims. The discussion of Plato's conception of the place of reason in affective life, as well as in moral reflection, is valuable, not only for the light it casts on the theory of education in The Republic, but also as a timely foil for the galloping "subjectivism" characteristic of many approaches to moral education (the "values clarification" movement inspired by Simon, Raths and Harmin comes immediately to mind as a paradigm example of this trend).

In Chapter 10, Scolnicov restricts his focus to Chapters V-VII of The Republic in order to develop Plato's view of the relation between knowledge and opinion. He shows that, in contrast to the view presented in the Meno (where knowledge is held to imply a context of reasons), The Republic provides a more elaborate ontological grounding for the distinction between knowledge and opinion, one in which knowledge is of what is as it is (i.e., knowledge is correct apprehension of the forms). In the final chapter of the book, Scolnicov looks at Plato's conception of literature and drama as presented in Chapters II, III, and X of The Republic. He shows that Plato's understanding of myth allows for a distinction to be drawn between myths which merely portray human beings as they are qua psychological and biological beings, and myths which present human beings with representations of an ideal reality. The former are "false" in that they fail to edify. The latter are "true" in that they are windows on eternity.

Scolnicov's book is interesting to read and provides much needed background for a better understanding of Plato's theory of education. Despite its virtues, however, it does suffer from some avoidable shortcomings. Scolnicov's prose style is too often tortured and unnecessarily difficult to understand. The help of a good editor would have resulted in a more fluid text. More importantly, Scolnicov fails to suggest weaknesses in the Platonic themes he discusses and he does not provide a focus in contemporary philosophy of education in comparison with which Plato's ideas could be assessed. Although his book is, quite clearly, intended to be a sympathetic exegesis of Plato's thinking on education and its underlying presuppositions, it does not follow from this that some modicum of critical perspective is, therefore, out of place. Finally, it is, indeed, unfortunate that Scolnicov did not see fit to conclude his book with a chapter outlining his view of the methodological implications of Plato's conception of philosophy for the philosophy of education as it is currently practised.

The main audience for this book would appear to be philosophers of education, philosophers, and Plato scholars. It is short enough to be profitably used as a background text in a course devoted to the investigation of the dialogues which it treats. Undergraduate students, however, would almost certainly find it difficult to read. 